\title{
DESKRIPSI JAMUR ENDOFIT DARI TUMBUHAN RARU (Cotylelobium melanoxylon) GENUS BOTRYTIS
}

\author{
Uswatun Hasanah dan Idramsa*) \\ Surel: uswatunhasanah@gmail.com
}

\begin{abstract}
ABSTRACK
This study aims to identify the endophytic fungus from the bark of the plant raru (Cotylelobium melanoxylon). This study uses identification technique manually by viewing and comparing the macroscopic and microscopic morphological characteristics of each isolate endophytic fungi then seek to obtain dendogram similarity index which divides each isolate into several clusters/genus. Data were analyzed using cluster analysis Simple Matching Coefficient in the Multi Variate Statistical Package (MVSP) where each isolate that had $\geq 70 \%$ similarity indices are grouped into one cluster/genus. The results of cluster analysis to get 8 cluster/genus endophytic fungi found in the bark of plants raru (Cotylelobium melanoxylon). Eighth genus included the genus Alternaria, Aspergillus, Botrytis, Debaromyces, Fusarium, Mycelia sterile, Nigrospora, and Scopulariopsis. This paper presents a description of the genus Botrytis.
\end{abstract}

Kata Kunci: Identifikasi, Jamur Endofit, Cotylelobium Malanoxylon, Indeks Similiritas

\section{PENDAHULUAN}

$\mathrm{T}$

umbuhan

melanoxylon tumbuhan yang hidup pada daerah beriklim tropis dan tumbuh tersebar di pulau Sumatera, Kalimantan (Kartasaputra \& Martawijaya, 1979), hingga ke semenanjung Malaysia dan Thailand (Anonymous, 2012). Tumbuhan $C$. melanoxylon adalah tumbuhan tahunan yang berperawakan pohon. Tumbuhan ini dikategorikan masuk daftar merah (red list) sebagai tumbuhan yang terancam langka (endangered) yang ditetapkan oleh International Union for Conservation of Nature (IUCN) pada tahun 1998 (Anonymous, 2012). Sebagian masyarakat Tapanuli Utara menggunakan bagian, kulit batang dan daun tumbuhan untuk mengobati penyakit diare, malaria, dan diabetes (Soerianegara \& Lemmens, 1994). Penelitian terdahulu oleh Matsuda et al. (2009) membuktikan bahwa kulit batang $C$. melanoxylon mengandung senyawa yang terdiri dari ampelopsin $\mathrm{F}$, isoampelopsin F, E-viniferin, vaticanol A, E, G, dan lyoniresinol yang berguna sebagai obat antidiabetes.

Mikroba endofit merupakan mikroorganisme yang mengkolonisasi bagian dalam jaringan tumbuhan dan berinteraksi dengan tumbuhan inang tanpa menimbulkan gejala atau penyakit pada tumbuhan yang

* ) Dra. Uswatun Hasanah, M.Si: Dosen Jurusan Biologi FMIPA UNIMED

Idramsa: Mahasiswa Jurusan Biologi FMIPA UNIMED 
ditumpangi (Zinniel et al., 2002; Hung and Annapurna 2004; Lima et al., 2005). Mikroba endofit ini terdiri dari bakteri dan jamur (Strobel \& Daisy, 2003). Isolasi jamur endofit pada berbagai macam tanamantanaman telah banyak dilakukan. terutama pada tanaman budidaya. Pencarian senyawa metabolit sekunder dari mikroba endofit pada berbagai tanaman, menarik dan penting untuk dilakukan (Tenguria et al., 2011). Mengingat, adanya berbagai masalah di bidang kesehatan seperti beragamnya jenis penyakit kanker, adanya resistensi bakteri terhadap obat-obatan, merebaknya penyakit yang disebabkan oleh protozoa (Strobel, 2003), sehingga diperlukan upaya untuk menemukan sumber obat alami yang baru (Castilo et al. 2006).

Pada makalah ini akan dideskripsikan salah satu genus jamur endofit yang ditemukan di dalam kulit batang tumbuhan raru (Cotylelobium melanoxylon) berdasarkan analisis cluster menggunakan Simple Matching Coefficient dalam program Multi Variate Statistical Package (MVSP) yaitu Isolat RJ-2, 13, 14, dan 2B dikelompokkan dalam satu klaster/genus karena keempat isolat tersebut memiliki indeks similaritas berdasarkan analisis SMC yaitu 0,848 atau $84,8 \%$ dan berdasarkan karakteristik morfologi makroskopis dan mikroskopisnya keempat isolat tersebut merupakan genus Botrytis.
METODE PENELITIAN Tempat dan Waktu Penelitian

Penelitian dilakukan di Laboratorium Mikrobiologi Jurusan Biologi FMIPA Universitas Negeri Medan. Penelitian dimulai bulan April 2014 sampai Juli 2014

Alat dan Bahan

a. Alat

Alat yang digunakan dalam penelitian ini yaitu Autoklaf (TOMY ES-315), Laminar Air Flow (Streamline ${ }^{\circledR}$ Model SHC-4A1), Inkubator, Magnetik Stirer (BIOSAN MHS-300), Mikropipet dan tip ukuran $1 \mu 1$, Cawan petri (HERMA), Jarum ose, Lampu bunsen, Mikroskop (ZEISS Axio Imager A1 dan OLIMPUS®), Kamera (Kodak EasyShare M530), Jangka Sorong, Erlenmeyer ukuran $250 \mathrm{ml}$ dan $500 \mathrm{ml}$ (PYREX), Gelas ukur ukuran 500ml dan 1000ml (PYREX), Timbangan digital (AND HR-200), Gunting tanaman steril, Pinset steril, Pisau, Botol kaca, Sikat gigi, Spidol, Objek glass, dan Cover glass.

b. Bahan

Bahan yang digunakan dalam penelitian ini adalah Kulit batang tumbuhan Raru (Cotylelobium melanoxylon) yang diperoleh langsung dari hutan Desa SibungaBunga, Kecamatan Sitahuis, Kabupaten Tapanuli Tengah, Kentang, Dextrose, Agar, Malt Extract, Yeast Extract Agar (YEA), Aquades, Ethanol 96\%, Ethanol 70\%, 
Sodium Hypocloride, Aquades Steril, Amoxicillin, Akhohol 70\%, Lactophenol Blue, Minyak Imersi, Sabun, Kertas Saring, Kertas pembungkus, Kertas Label, Kertas Aluminium Foil, Plastik Seal/ isolatip, Kapas, Plastik Kaca dan Kertas Tissue.

\subsection{Prosedur Penelitian}

Penelitian dilakukan dalam beberapa tahap yaitu

(1). Pengumpulan Sampel

(2). Pembuatan Media

(2.1). Potato Dextrose Agar (PDA)

(2.2). Malt Extract Agar (MEA)

(2.3). Yeast Extract Agar (YEA)

(3). Sterilisasi Permukaan

(4). Isolasi Sampel

(5). Pemurnian Isolat

(6). Identifikasi dan Karakterisasi

\section{(6.1). Karakteristik Makroskopik}

Mengamati karakteristik makroskopik jamur endofit yang tumbuh pada media PDA sesuai dengan metode identifikasi oleh Gandjar, $d k k$ (1999) dan Malloch (2000) meliputi: (1) Warna koloni, (2) Bentuk koloni, (3) Tekstur koloni, (4) Bentuk tepian koloni, (5) Diameter koloni, (6) Topografi koloni, (7) Warna sebalik koloni (reserve side), (8) Permukaan koloni, (9) Tinggi koloni (mm), (10) Lingkaran konsentris ada atau tidak, (11)Garis radial dari pusat koloni ke arah tepi koloni ada atau tidak.

\section{(6.2). Karakteristik Mikroskopik}

Pengamatan karakteristik mikroskopik jamur endofit meliputi: (1) Sel tunggal atau banyak, (2) Sel berdinding halus atau kasar, (3) Hifa bersepta atau tidak, (4) Hifa berpigmen atau tidak, (5) Bentuk hifa (spiral, bernodul, atau mempunyai rizoid), (6) Miselium terang atau keruh, (7) Miselium berwarna atau tidak, (8) Memproduksi spora atau tidak, (9) Spora seksual atau aseksual, (10) Spora aseksual berbentuk sederhana atau khusus, (11) Spora aseksual bersel banyak atau tidak, (12) Jenis spora aseksual, (13) Bentuk spora aseksual, (14) Pengaturan spora aseksual (diproduksi tunggal, berantai, atau berbentuk klaster), (15) Spora dibentuk di dalam tubuh buah (pycnidium) atau tidak, (16) Spora dibentuk di dalam rantai (chain) atau tidak, (17) Ukuran sporangium, (18) Warna sporangium, (19) Bentuk sporangium, (20) Letak sporangium, (21) Bentuk spora seksual, (22) Kepala spora pembawa konidia (tunggal, berantai, bentuk, dan rangkaian sterigmata),

Penampakan sporangiofor/ konidiofor (sederhana atau bercabang), (24) Bentuk percabangan sporangiofor/ konidiofor, (25) Konidiofor berbentuk kompleks atau sederhana, (26) Warna konidiofor, (27) Konidiofor berdinding kasar atau halus, (28) Konidiofor diproduksi dalam kelompok (sporokhia) atau tidak, (29) Ukuran kolumela pada ujung 
sporangiofor, (30) Bentuk kolumela pada ujung sporangiofor, (31) Konidiofor tunggal atau berkumpul, (32) Bentuk konidia, (33) Ukuran konidia, (33) Warna konidia, (34) Konidia/ spora bercabang atau tidak, (35) Permukaan konidia (halus atau kasar), (36) Konidia satu atau banyak sel, (37) Stolon ada atau tidak, (38) Rizoid ada atau tidak, (39) Footcell ada atau tidak

Prosedur kerja penelitian yang dilakukan pada tahun pertama disajikan dalam bentuk skema pada Gambar 1 di bawah ini.

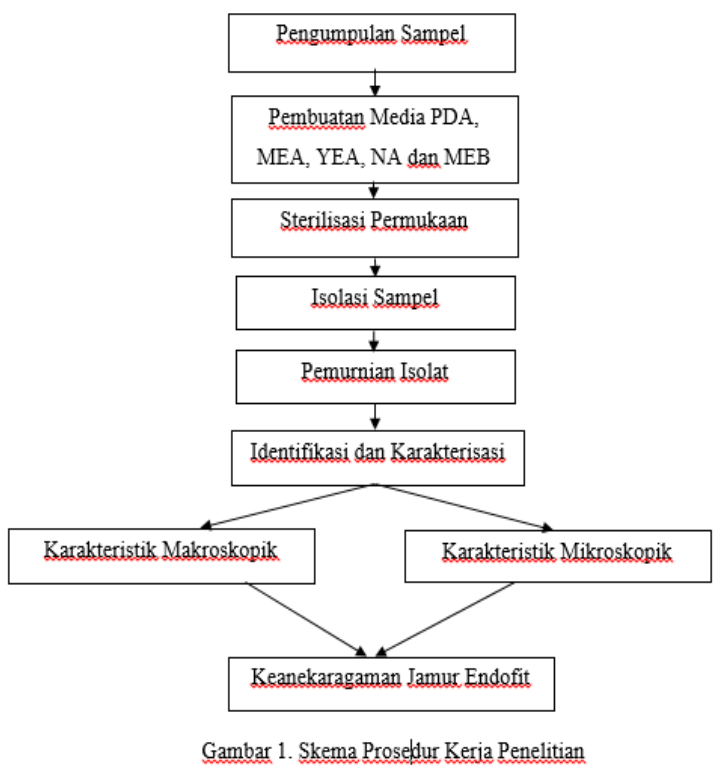

\section{HASIL DAN PEMBAHASAN}

Hasil analisis klaster menunjukkan bahwa genus Botrytis yang ditemukan di dalam sampel kulit batang tumbuhan raru (Cotylelobium melanoxylon) terdiri atas empat Isolat yaitu RJ-2, 13, 14, dan 2B dikelompokkan dalam satu klaster/genus karena keempat isolat tersebut memiliki indeks similaritas berdasarkan analisis SMC yaitu 0,848 atau $84,8 \%$ dan berdasarkan karakteristik morfologi makroskopis dan mikroskopisnya keempat isolat tersebut merupakan genus Botrytis. Deskripsi dari masing-masing isolat dijelaskan pada alinea berikut ini.

\subsection{Isolat RJ-2}

Koloni tumbuh sangat cepat pada medium PDA, dengan diameter $9 \mathrm{~cm}$ dalam 3 hari. Koloni berwarna putih kekuningan, menyebar, bertekstur cottony (seperti kapas), dengan tepian rata seperti benangbenang. Permukaan koloni halus, topografi koloni verugose (kusut dan keriput), warna sebalik koloni (reserve side) putih kekuningan, tinggi koloni $7 \mathrm{~mm}$, tidak terdapat lingkaran konsentris dan garis radial. Miselium terang, tidak berwarna, bersel banyak dan berdinding halus. Hifa tidak bersepta dan tidak berpigmen, berbentuk spiral. Memproduksi spora aseksual berbentuk khusus, bersel banyak, dengan spora berjenis konidia, berbentuk bulat, dan diproduksi dalam klaster. Sporangium berukuran kecil (1-5 mm), bulat, hialin, dan terletak di ujung. Kepala spora pembawa konidia berantai dan bulat. Konidiofor bercabang, kompleks, berwarna hialin, berdinding halus, diproduksi dalam kelompok, dan tunggal. Kolumela pada ujung konidiofor berukuran kecil (1-5 mm), dan berbentuk semi bulat. Konidia 
berbentuk bulat, kecil (1-5 $\mathrm{mm})$, berwarna hialin, halus, dan bersel satu.
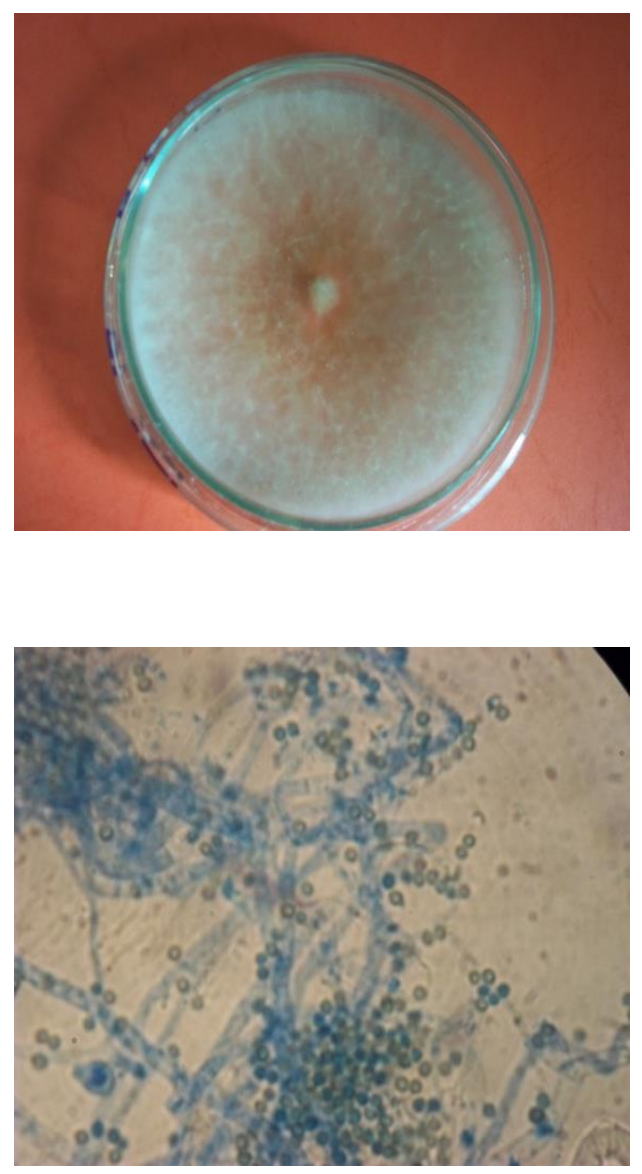

Gambar 2. RJ-2 koloni (a) dan morfologi mikroskopis koloni (b)

\section{Isolat RJ-13}

Koloni tumbuh sangat cepat pada medium PDA, MEA, dan YEA, dengan diameter $9 \mathrm{~cm}$ dalam 3 hari. Koloni berwarna putih kekuningan, meyebar, cottony, dengan tepian seperti benang-benang. Permukaan koloni halus, verugose, warna sebalik koloni putih kekuningan, tinggi koloni $8 \mathrm{~mm}$, tidak terdapat lingkaran knsentris dan garis radial. Miselium terang, tidak berwarna, bersel bannyak dan berdinding halus. Hifa tidak bersepta, tidak berpigmen, dan berbentuk spiral. Memproduksi spora aseksual berbentuk khusus, bersel banyak, berjenis konidia, bulat, berbentuk klaster, dan dibentuk di dalam rantai. Sporangium berukuran kecil, hialin, bulat hingga semi bulat, dan terletak di ujung. Kepala spora pembawa konidia berantai berbentuk bulat. Konidiofor bercabang, kompleks, hialin, berdinding halus, diproduksi dalam kelompok dan berkumpul. Kolumela pada ujung konidiofor berukuran kecil dan berbentuk elips hingga semi bulat. Konidia bulat, kecil (1-5 mm), hialin, halus, dan bersel satu.

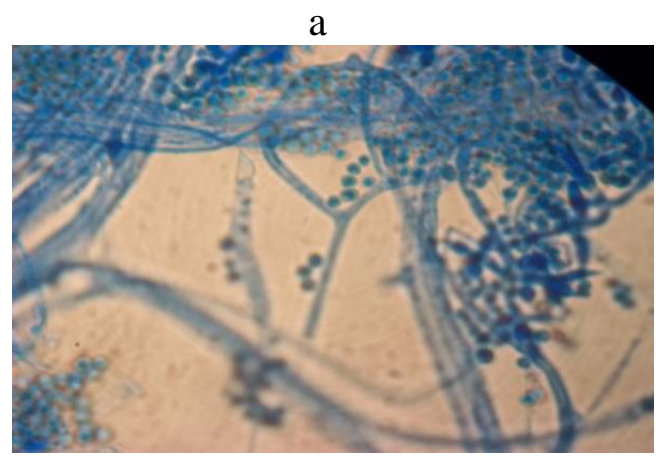

b

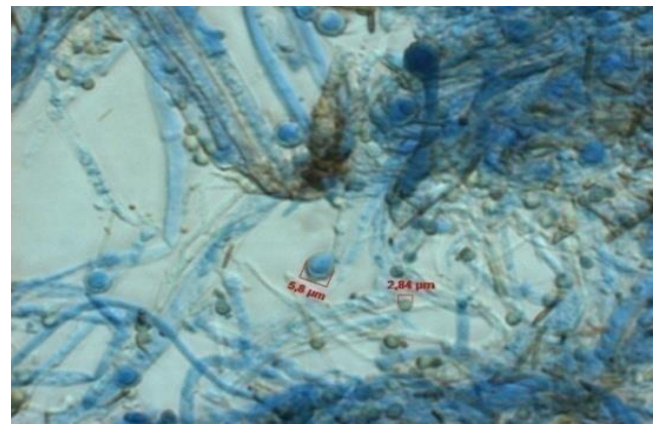




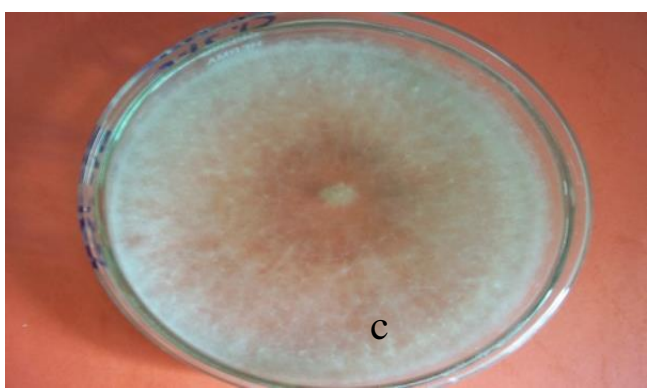

Gambar 3. RJ-13 koloni (a) dan morfologi mikroskopis konidia (b dan c)

\section{Isolat RJ-2B}

Koloni tumbuh sangat cepat pada medium PDA, dengan diameter $8,7 \mathrm{~cm}$ dalam 3 hari, 8,3 $\mathrm{cm}$ pada medium MEA dalam 3 hari, dan $5,8 \mathrm{~cm}$ pada medium YEA dalam 3 hari. Koloni berwarna putih kehijauan, menyebar, bertekstur cottony (seperti kapas), dengan tepian seperti benang-benang. Permukaan koloni halus, topografi koloni verugose (kusut dan keriput), warna sebalik koloni (reserve side) putih kehijauan, tinggi koloni $2 \mathrm{~mm}$, dan terdapat lingkaran konsentris. Miselium terang, tidak berwarna, bersel banyak dan berdinding halus. Hifa tidak bersepta dan tidak berpigmen, berbentuk spiral. Memproduksi spora aseksual berbentuk sederhana, bersel banyak, dengan spora berjenis blastospora, berbentuk bulat, berantai dan dibentuk di dalam rantai. Sporangium berukuran kecil (1-5 mm), bulat, hialin, dan terletak diujung. Kepala spora pembawa konidia berantai. Konidiofor bercabang, sederhana, berwarna hialin, berdinding halus,diproduksi dalam kelompok, dan tunggal. Kolumela pada ujung konidiofor berukuran kecil (1-5 mm), berbentuk bulat, dan berkumpul. Konidia berbentuk bulat, kecil (1-5 $\mathrm{mm})$, berwarna hialin, halus, dan bersel satu.

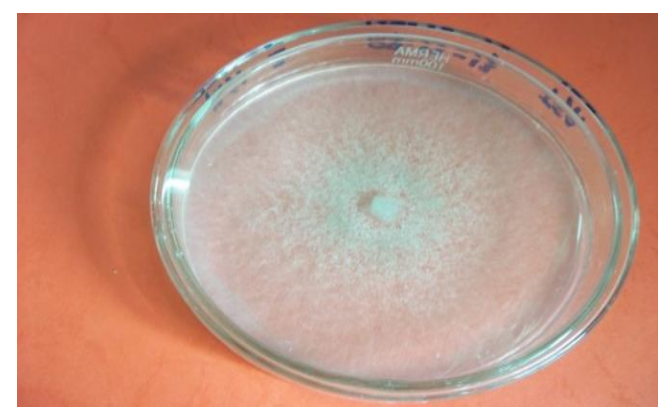

a

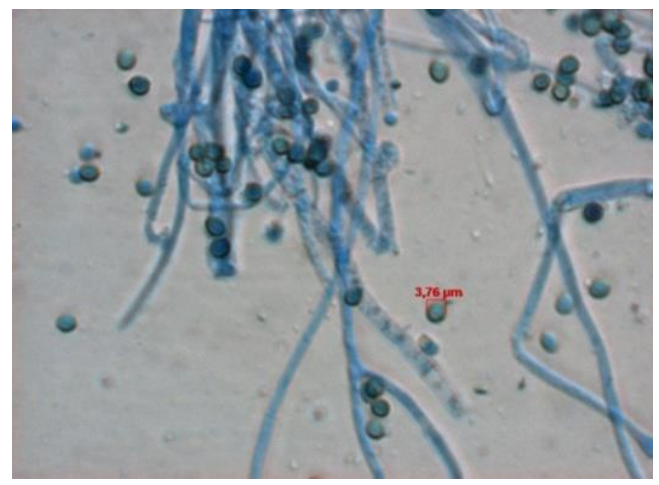

b

Gambar 5. RJ-2B koloni (a) morfologi mikroskopis konidia (b)

Menurut Gandjar, $d k k$ (1999), koloni semula berwarna hialin hingga putih, kemudian menjadi abu-abu hingga abu-abu kecoklatan. Konidiofor muncul tidak teratur tanpa pembengkakan basal, mempunyai panjang $750 \mu \mathrm{m}$ hingga lebih dari 2 $\mathrm{mm}$, mempunyai lebar 16-30 $\mu \mathrm{m}$, pada bagian basis berwarna coklat, berdinding halus, dan pada bagian apikal tterdapat percabangan. Konidia berbentuk obovoid, berwarna coklat pucat, berdinding halus, dan berukuran (8-14) x (6-9) $\mu \mathrm{m}$. Pembentukan konidia umumnya 
simultan pada pembengkakan dari ujung percabangan konidiofor, dan membentuk sporangiola. Sedangkan Malloch (2000) berpendapat bahwa spora (konidia) terbentuk dari percabangan yang terakhir dan diproduksi secara synchron. Ketika koloni mulai menjadi kering, sel konidiofor sering merata satu sama lain.

\section{KESIMPULAN}

\section{Simpulan}

Genus Botrytis memiliki koloni berwarna putih kekuningan, menyebar, cottony, dengan tepian seperti benang. Permukaan koloni halus, verugose, warna sebalik koloni putih kekuningan, dengan tinggi koloni $8 \mathrm{~mm}$, tidak terdapat lingkaran konsentris dan garis radial.

\section{Saran}

Dari hasil penelitian yang telah dilakukan, peneliti menyarankan agar melakukan penelitian lanjutan dengan menggunakan analisis tingkat molekuler untuk mengetahui kekerabatan antara isolat jamur endofit dari kulit batang tumbuhan Raru (Cotylelobium melanoxylon) pada genus Botrytis.

\section{DAFTAR PUSTAKA}

Anonymous. 2012. The IUCN Red List of Treatened Species: Cotylelobium melanoxylon. (www.iucnredlist.org/details/33070/ 0). Diakses tanggal 22 Desember 2012.
Castillo, U.F., Strobel, G.A., Mullenberg, K., Condron, M.M., Teplow, D.B., Folgiano, V. Gallo, M. Ferracane, R. Mannina, L., Viel, S., Codde, M. Robison, R. Porter, H., and Jensen, J. 2006. Munumbicin E-4 and E5: novel broad-spectrum antibiotics from streptomyces NRRL 3052. Microbiol Lett. 255: 296-300.

Gandjar, I., Robert A. S., Karin, T. V., Ariyanti, O., dan Iman, S., (1999), Pengenalan Kapanng Tropik Umum, Yayasan Obor Indonesia, Jakarta.

Hung, P.Q., and Annapurna, K. 2004. Isolation and characterization of endophytic bacteria in soybean (Glycine sp.). Omonrice. 12: 92-101.

Lima, A.O., Quecine, M.C., Fungaro, M.H.P., Fernando, D.A., Maccheroni Jr, W., Araujo, W.L., Silva-Filho, M.C., Pizzirani-Kleiner, A.A., and Azevedo, J.L. 2005. Molecular characterization of a $\beta-1,4-$ endoglucanase from an endophytic Bacillus pumilus strain. Appl. Microbiol Biotechnol. 68: 57-65.

Matsuda, H., Aso, Y., Nakamura, S., Hamao, M., Sugimoto, S., Hongo, M., Pongpiriyadacha, Y., and Yoshikawa, M. 2009. Antidiabetogenic constituents 
from the thai traditional medicine Cotylelobium melanoxylon.

(http://www.ncbi.nlm.nih.gov/pubme d/19420780). Diakses tanggal 13 April 2010.

Malloch, D., (2000), Moulds: Their Isolation, Cultivation, and Identification, University of Toronto Press, Toronto.

Soerianegara, I dan R.H.J. Lemmens. 1994. Plant Resources of South-East Asia No.5(1). Timber Trees: Minor Comercial Timbres. Prosea Foundation, Bogor, Indonesia. Leiden: Backhuys.

Strobel G.A., 2003. Endophytes as sources of bioactive products. Microbes and Infection. 5. 535-544.

Strobel G, and Daisy B, 2003. Bioprospecting for microbial endophytes and their natural products, Microbiology and Molecular Biology Review 67: 491-502.

Tenguria, R.K., Khan, F.N., and Quereshi, S. 2011. Endophytesmines pharmacological therapeutics. World Journal of Science and Technology. 1(5): 127-149

Zinniel, D.K., Lambrecht, P., Harris, N.B., Feng, Z., Kuczmarski, D., Higley, P., Ishimaru, C.A., Arunakumari, A., Barletta, R.G., and Vidaver, A.K. 2002.
Isolation and characterization of endophytic colonizing bacteria from agronomic crops and prairie plants. Applied and Enviromental Microbiology. 68: 2198-2208. 